\title{
Chapter 2 \\ Dispersal and Reception in Northern Italy: Comparing Systems Along the Brenner Route
}

\author{
Michela Semprebon and Gracy Pelacani
}

\subsection{Introduction}

In the last decades, the European Union's migration policy has been increasingly criticized for its imbalance towards border control and the fight against what policymakers define as "illegal migration" rather than the reception and the protection of seekers and holders of international protection. An increasing number of policy restrictions and practices have curtailed the rights of both groups of migrants (Morris 2002; Tyler 2010), thus impacting on their lives as well as on the territories they transit through.

Dispersal schemes are an element of this policy scenario. They feature in various EU member states, including Italy (Boswell 2001; Robinson et al. 2003), as part of an articulated multi-level policy framework. Within this framework, local authorities and the third sector play a crucial role in dealing with the arrival and reception of seekers and holders of international protection and with the difficulties due to inadequate EU and national reception systems.

In 2011, with the outbreak of the Arab Spring and the reprise of considerable migration flows towards EU member states, the political discourse on asylum and migration policy came to be dominated by an "emergency" frame again (Campesi 2011; Marchetti 2012; Dal Zotto 2014), often invoked to legitimise the unpreparedness of national governments to cope with migration. In 2013 and 2014, as the Syrian civil war escalated, a growing diversification and fragmentation of migration trajectories added to this (perceived) emergency due to the increasing numbers of

\footnotetext{
M. Semprebon $(\bowtie)$

SSIIM UNESCO Chair, Università IUAV, Venice, Italy

e-mail: msemprebon@iuav.it

G. Pelacani

Facultad de Derecho, Universidad de los Andes, Bogotá, Colombia

e-mail: g.pelacani@uniandes.edu.co

B. Glorius, J. Doomernik (eds.), Geographies of Asylum in Europe and the Role of European Localities, IMISCOE Research Series, https://doi.org/10.1007/978-3-030-25666-1_2
} 
Syrians and Eritreans arriving on southern Italian shores in order to reach Northern Europe, particularly Germany and Sweden.

In this context, temporary controls were re-introduced several times at Brenner, one of the Italian points of access to Austria, pursuant to Article 25 et seq. of the Schengen Borders Code, providing EU member states with the possibility of introducing temporal controls at internal borders in the event of serious threats to internal security. Regular random police inspections have been operated since by German, Austrian and Italian police forces on trains and in train stations along the Brenner route, from Verona to Brenner, and further north, in Rosenheim and Munich (Antenne Migranti and ASGI 2017).

In addition, several agreements have been signed between Italy and Austria in this regard. ${ }^{1}$ Border enforcement was particularly strengthened in 2015 (for a good explanation on this, see Fontanari and Borri 2017); and, in the same year, Austria declared its intention to tighten controls on its border with Italy (European Commission 2015). It was a time when the cross-border mobility of seekers and holders of international protection was hardly evident to the wider public opinion. On their side, national institutions had been tolerating what were understood as marginal "secondary movements" (Scalettaris 2007). These resulted from a national strategy of "laissez-passer" (Ciabarri 2015), implemented, similarly to Greece, to cope with growing arrivals. ${ }^{2}$

Holders of humanitarian protection ${ }^{3}$ were increasingly pushed to the margins of society. Some of them tried to travel to Northern Europe to look for better settlement opportunities, thus making the inadequacy of the Dublin system more evident (Morano-Foadi 2017). Other migrants included people performing autonomous journeys (Kasparek 2016) along the Balkan route, which was closed in summer 2015, and from Southern Italy, in the period that preceded the full operation of the

\footnotetext{
${ }^{1}$ For further details see Antenne Migranti and ASGI (2017). In 2014, an agreement regulated controls on passenger trains, and in 2017 on freight trains. The former agreement was ratified by both the Italian government (Legge del 03/11/2016 nr. 209, G.U. 21/11/2016) and Austrian government (Bundesgesetzblatt Nr. BGBl. III Nr. 47/2017). For further details see Antenne Migranti and ASGI (2017) and Monika Weissensteiner "Da Lampedusa al Brennero", Una città. http://www.unacitta. it/flip/lampedusa-brennero/files/assets/basic-html/page39.html. Accessed 5 July 2018. As regards the latter agreement see Ansa "Austria, Controlli treni merci al Brennero", http://www.ansa.it/ trentino/notizie/2017/11/15/austria-controlli-trilaterali-brennero_5266a464-914d-4930-a7cf8bc5e7004224.html. Accesses 1 July 2018.

${ }^{2} \mathrm{Cf}$. Infringement procedure opened against Italy for the incorrect implementation of the Eurodac Regulation (n. 20152203) notified on 10/12/2015. European Commission - Press release, 10th Dec. 2015. http://europa.eu/rapid/press-release_IP-15-6276_EN.htm. Accessed 20 June 2018.

${ }^{3}$ The humanitarian protection is a national status granted by the Italian government to asylum seekers in situations not typified by LD. 286/1998 (arts. 5.6, 19.1), that is to say whenever there are serious reasons, of humanitarian nature, or resulting from constitutional or international obligations. It applies to applicants whose refugee status or right to subsidiary protection cannot be recognized, but who can also not be expelled in accordance with the principle of non-refoulement. However, the LD. 113/2018 (in force since October 2018, and converted into Law 132/2018) has partially modified the grounds on which humanitarian protection is given, by limiting the ground on which this status can be granted and adding three other "special" permits, two based on humanitarian grounds (medical reasons and natural disasters) and another for special civil merits.
} 
hotspot system (Sciurba 2017), aimed at boosting compliance with the Eurodac (n. 603/2013) and the Dublin III Regulations (Casolari 2016). Many became stuck at Ventimiglia, a border crossing point with France, or Como-Chiasso, at the border with Switzerland, and were repeatedly transferred back to the hotspot areas (Tazzioli 2017). The same happened at Brenner, the main point of access to Austria.

This is how these locations transformed into internal hotspots (see also Denaro 2016 on Milan) characterised by more and more systematic border enforcement practices. ${ }^{4}$ They have also become "spaces of transit" (Tazzioli 2017). Therefore, several local actors have been "forced" to activate accordingly, in order to deal with migrants being "stuck" while trying to transit through these spaces towards Northern Europe. In particular, we are referring to migrants arriving by land through the Balkan route, holders of humanitarian protection wanting to leave Italy, migrants re-admitted to Italy in application of the Dublin Regulation or entering Italy to reapply for international protection, and asylum seekers leaving a reception centre in Italy (due to unsustainable living conditions) despite a pending asylum application in the country.

The fact that none of these migrants can easily access (or benefit from) the reception system points to some critical issues. Firstly, transit across Europe has affected the rights and conditions of seekers and holders of international protection. Secondly, it has put reception actors in some border locations under more strain. Growing interest has been paid to the crucial role of civil society in dealing with them, as well as with undocumented migrants (e.g. Ambrosini 2018). Less attention has been given to how and the extent to which the public sector has been activated to deal with their presence on their territory, for a more or less limited time. This is the focus of this chapter.

By drawing from the work of Caponio and Borkert (2010) on the multilevel governance of migration, and the work of Mezzadra and Neilson (2016) on the proliferation of heterogeneous forms of borders, we discuss the specific scenario along the Brenner route, and how and to what extent the respective local systems of reception have catered (or not) for migrants that policy-makers often define "in transit" and who (at a certain stage) have fallen out of the ordinary system of dispersal.

The chapter is structured as follows: first, an overview will be given of the current system of reception in Italy and of the critical issues that have emerged over the most recent years. Second, we will set our contribution into the context of the wider academic debate on reception systems and how and whether these have responded to migrants. Then, we will focus on three cities along the Brenner route-Verona,

\footnotetext{
${ }^{4}$ Papers on these localities have been presented in the panels "Ethnographies of asylum seekers reception" coordinated by Semprebon and Marzorati http://www.etnografiaricercaqualitativa.it/ GeneralProgramme at the Ethnography and Qualitative Research Conference in Bergamo 6th-9th Jun. 2018 and by Fontanari, Gennari, Caprioglio, Ferri http://users2.unimi.it/escapes/ escapes2018/escapes2018-programma/\#28p at the Escapes Conference in Milan 28th-29th Jun. 2018.
} 
Trento and Bolzano - and will look at the similarities and differences characterising their respective reception systems. To conclude, we will make some final remarks and provide recommendations for policy-making.

\subsection{The Current System of Reception in Italy}

Italy is characterised by a double-track reception system: an ordinary and an extraordinary one. The origins of the ordinary system can be traced back to the "Piano Nazionale di Asilo" (National Asylum Plan) (1999-2001) when a first attempt was made to create a reception network with the involvement of local communities (Hein 2010).

In 2001, the Ministry of Interior, ANCI (the Associazione Nazionale Comuni Italiani - National Association of Italian Municipalities) and the UNHCR signed a memorandum of understanding establishing the first public reception network in Italy, which was institutionalized by Law 89/2002 under the name of "SPRAR" (Sistema di protezione per richiedenti asilo e rifugiati - Protection system for asylum seekers and refugees).

In 2011, a parallel emergency system of reception was set up in order to cope with the increasing number of arrivals by sea that followed the outbreak of the Arab Spring and a chaotic situation in Libya. In April 2011, the Italian Ministry of Interior launched the Emergency North Africa Program, which ended in December 2012. Extraordinary reception centres were opened to provide a temporary solution, aimed to complement the limited capacity of the ordinary system.

Over time, due to the persistent inability of the ordinary system to cope with arrivals, the extraordinary system was consolidated and was finally institutionalized in 2014, on the basis of an understanding among the State, the Regions and local entities. ${ }^{5}$ This was meant to favour the coordination of all government levels involved in reception and to lead to the absorption of the extraordinary system into the ordinary one, by promoting a two-level system.

The current system is structured as follows: upon migrants' arrival, medical assistance is provided and identification procedures are carried out in hotspots or at the ports of arrival, although they partly still take place in the CPSAs (Centri di Primo Soccorso e Accoglienza - Centres of first medical aid and reception). Next, migrants who express the intention to apply for international protection are taken to collective governmental reception centres (CPAs, Centri di Prima Accoglienza Centres of first reception). When places are insufficient, migrants are distributed across temporary centres, the so-called CASs (Centri di Accoglienza Straordinaria Centres of Extraordinary Reception), located throughout the country. The distribu-

\footnotetext{
${ }^{5}$ Conferenza Unificata Stato-Regioni, Intesa tra il Governo, le Regioni e gli Enti locali sul piano nazionale per fronteggiare il flusso straordinario di cittadini extracomunitari, adulti, famiglie e minori stranieri non accompagnati, 10.07.2014. http://www.statoregioni.it/Documenti/ DOC_044430_77\%20CU\%20PUNTO\%202\%20ODG.pdf. Accessed 20 June 2018.
} 
tion takes place according to a system of progressive quotas, taking into consideration regions' number of asylum seekers with respect to the total number of inhabitants and the percentage of access to funding from national funds for social policy. ${ }^{6}$ Finally, asylum seekers are transferred to a SPRAR structure, if places are available. $^{7}$

According to the most recent data available, on 31st December 2016, $73 \%$ of migrants were hosted in CAS structures, $7.8 \%$ in other structures of first reception (CPAS, CDA, CARA), $0.4 \%$ in hotspots and $18.7 \%$ in SPRAR structures. This makes it evident that although the SPRAR system is supposed to be the main element of the reception system, it is still far from being so, mainly due to insufficient places being available (SPRAR report 2017).

\subsubsection{The SPRAR Network and the CAS}

The SPRAR network consists of a network of reception projects, funded through resources made available by the National Fund for Asylum Policies and Services (funded in turn by the EU Asylum, Migration and Integration Fund). Local entities join the network on a voluntary basis, by applying for funding. Each reception project must be approved by the Central Service (Servizio Centrale), which is the SPRAR's coordinating body. Requirements include first and foremost the acceptance of a public authority to take responsibility as the main signatory. Projects last 3 years, are renewable, and the National Fund covers $95 \%$ of the total costs. ${ }^{8}$

The network operates on a multi-level logic, through the decentralisation of project management: the implementation of activities is delegated to private actors, encouraging the activation of synergies between the public and third sectors.

In 2016, 652 SPRAR projects were funded: 508 targeting ordinary beneficiaries, 99 unaccompanied minors and 45 migrants with physical and/or mental vulnerability or disability. Since its creation, the network has grown considerably from 1365 available places in 2003 to more than 26,000 in 2016.

As indicated in the 2017 SPRAR report, in 2016, the ordinary system started giving priority of access to migrants who had already obtained a form of international protection, in line with the idea that the SPRAR should become the primary infrastructure to facilitate the integration of migrants. The Law 132/2018 (in force since October 2018) established that only holders of refugee status or subsidiary protection, unaccompanied minors, holders of permits granted for medical reasons, victims of natural disasters, those with civil merits and other limited special cases can access a SPRAR project. The SPRAR was renamed SIPROIMI, (Protection System for holders of international protection and unaccompanied minors - Sistema

\footnotetext{
${ }^{6}$ Supra note 6.

${ }^{7}$ For more details on reception structures see Accorinti (2015).

${ }^{8}$ See the SPRAR dedicated website. www.sprar.it. Accessed 5 January 2017.
} 
di Protezione per titolari di protezione internazionale e per minori stranieri non accompagnati).

SPRAR and (and similarly for SIPROIMI - but implementation guidelines have not been published yet) initiatives offer "integrated" reception services, with the main goal of supporting beneficiaries on their path towards autonomy. Apart from room and board, services should include health assistance, language and cultural mediation, social assistance, multicultural activities, support for job orientation and job seeking, and legal assistance. The actual standard of these services across the country is inconsistent. Standards of CAS services are not defined in the relevant normative framework (Lgs.D. 142/2015), but can be defined in the conventions signed between a CAS and a local prefecture ${ }^{9}$ or the prefecture and the local authority competent for the territory where the CAS is located. ${ }^{10}$

Reception facilities are of three types: 2873 small flats (83.3\% of structures in 2016), 357 collective centres (10.3\% in 2016) and 227 "comunità alloggio", which are community reception centres (6.6\% in 2016). Some structures are targeted to specific types of beneficiaries, such as unaccompanied minors, single women with children, and families.

The length of beneficiaries' stay in the centres varies depending on their status and personal situation, but also across projects, in relation to discretionary decisions on the side of operators. As far as seekers of international protection are concerned, reception is granted until a decision on the application is made. In case of rejection, their stay can be prolonged until the term to appeal the decision expires and, in case of appeal, as long as they are authorized to remain in the national territory (art. 14, Legislative Decree - from now onwards LD. - 142/2015).

As a result of an effort to simplify and accelerate the legal procedure after a negative decision by the Territorial Commission, the possibility to appeal the decision to a second instance was eliminated (LD. 13/2017). Rejected applicants can now only appeal directly to the Court of Cassation within 30 days (art. 6, co. 1, lett. g, LD. $13 / 2017,35$ bis, co, 13). In practice, their length of stay depends on the time it takes for the competent Territorial Commission to decide on the application: currently more than 300 days on average (AA.VV. 2017). For applicants that have obtained a form of international protection, their stay in reception centres should not exceed 6 months, but it can be extended on an individual basis - for example, if applicants do not have their own means of subsistence or are particularly vulnerable.

\footnotetext{
${ }^{9}$ The Prefecture is the headquarters of the Prefetto (Prefect) who represents the Ministry of Interior in each province.

${ }^{10}$ e.g. Prefecture of Rome http://www.prefettura.it/roma/allegati/Download:Cas_capitolato_tecnico_cig_695518503c-5854145.htm; Prefecture of Florence http://www.prefettura.it/FILES/allegatinews/1183/ALL_1_Convenzione_.pdf; Prefecture of Milan http://www.prefettura.it/milano/ allegati/Download:Allegato_b_schema_di_convenzione-5732499.htm. Accessed 20 August 2018.
} 


\subsubsection{Critical Issues Relating to the Reception System in the CAS and SPRAR Network}

Scholars have highlighted a range of critical issues connected to the reception systems in various EU countries. Some of these issues are (partly) relevant for the Italian system too. ${ }^{11}$

First, there has been a growing process of privatization of reception (Darling 2016), alongside limited accountability of the managing institutions. This concerns Italy too, particularly with reference to the CASs managed by private cooperatives.

Second, responsibility for reception has been increasingly delegated from the national to the local government, with scarce monitoring (Robinson et al. 2003). Similarly, repeated evidence by lasciateCIEntrare ${ }^{12}$ suggests that the Italian Ministry of Interior does not regularly undertake monitoring visits to the CASs, thus leaving them to the discretion of prefectures. On its side, SPRAR's Central Services has been undertaking a regular monitoring of projects' financial reports but also visits.

Third, minimum standards of services are not always guaranteed (Robinson et al. 2003). In the case of Italy the lack of homogeneity is evident in particular when comparing SPRAR and CAS structures (Marchetti 2016). SPRAR identified precise standards for the provision of services, financial reporting and monitoring, contrary to CAS structures, where the vast majority of beneficiaries of reception are hosted. At the same time, critical issues relating to standards also apply to some SPRAR structures, due to the consistent growth of the network and the fact that some operators are not yet sufficiently trained (Ambrosini and Marchetti 2008; Semprebon 2017). From this point of view, a reflection is needed on the effectiveness of LD. $142 / 2015$ in terms of granting minimum standards of reception to all seekers and holders of international protection (Marchetti 2016), considering the lack of homogeneous approaches to management and the provision of services.

Fourth, as anticipated, the approval of a SPRAR project is dependent on the voluntary decision of a public entity to take responsibility for the project. However, this does not always happen, as migration is a highly politicized issue and reception is often met by resistance from local residents (Marzorati and Semprebon 2018), also as a result of a diffused discriminatory discourse on immigration (Carta di Roma 2017). To date, the total number of public entities that have signed for a project amounts to 555, including 491 municipalities (out of a total of 8000 in Italy) - while 1000 authorities are involved in projects to a limited extent (SPRAR 2017). In this sense, the voluntary nature characterizing the activation of SPRAR projects has been strongly criticised (Penasa 2017).

Fifth, reception often seems to be geared towards the control of beneficiaries rather than their empowerment and integration, particularly in CAS structures (Griffiths et al. 2005). In Italy this has translated into rigid internal CAS regulations limiting individuals' personal autonomy, although they should be allowed to go out

\footnotetext{
${ }^{11}$ e.g. Ambrosini and Marchetti (2008); Scannavini (2010); Marchetti (2016)

${ }^{12}$ See http://www.lasciatecientrare.it/. Accessed 8 February 2018.
} 
during the day, as established for ordinary centres (art. 10.2, LD. 142/2015; Accardo and Guido 2016).

Sixth, and at a more macro level, critical issues of reception relate to the actual system of dispersal and the impact of beneficiaries' arrival in different contexts of reception. An overarching logic of "burden sharing" (Boswell 2001) still prevails and coexists with an approach that is still largely based on emergency management, despite the efforts to develop a system based on a constant and ex ante annual evaluation of reception needs. In fact, as expressly stipulated by LD. 142/2015 (art. 8), the national coordinating body is expected to adopt an annual reception plan based on a prediction of arrivals, which should define the number of places needed for reception. No other criteria are applied in the dispersal system. For example, no consideration is made to distribute beneficiaries where larger communities of conationals reside, in view of facilitating access to co-ethnic networks, contrary to what is suggested by evidence (for the UK: Bloch 2008).

Seventh, if we look at post-reception experiences, various reports by SPRAR highlight that only a few beneficiaries find employment and decent accommodation at the end of their stay in a reception project. Moreover, to date, even when beneficiaries are granted protection, they cannot benefit from any national integration programme; if they are rejected, they may return to (if ever having left) a state of marginality (Médecins Sans Frontières 2018; IntegrA/Azione 2012). Many of them may experience a sense of "institutional abandonment" (Agier 2005).

Finally, a more general critical aspect of the reception system in Italy relates to access. Some categories of migrants are de facto excluded or run a high risk of being excluded from it. These include migrants who are in transit, and who arrive by land and are not "dispersed" through the quotas defined by the Ministry of Interior (for migrants arriving by sea). The most recent amendment to the national legislation of international protection and reception (Cf. Law 132/2018) confirms this exclusionary trend.

\subsection{Reception in Transit Places: The Academic Literature}

As noted above, little attention has been paid to the public sector, and to how and to what extent it is activated to deal with migrants transiting through Europe. Particularly in the past decade, Italy has been understood and has considered itself as a gateway to Northern Europe. In this sense, it could seem paradoxical that the country has scarcely improved its capacity to deal with migrants that transit through border areas. However, as spelt out in LD. 142/2015, the right to reception is granted only to migrants who do not have any means of subsistence when they apply for international protection in Italy and for whom Italy is responsible according to the Dublin III Regulation.

What should be stressed is that access to reception, and connected rights, can be hindered even when these conditions are met: this is the case for migrants that arrive by land, typically through the Balkan route or who travel southwards through the Brenner Pass, following a rejected application for asylum in another EU member 
state. While migrants arriving on southern Italian shores enter the reception system through the system of dispersal (unless they refuse to do so or flee), migrants arriving by land can face considerable obstacles in accessing any form of protection. Even if they manifest their willingness to apply for asylum, the formalization of the application can take 1 month or more (AAVV 2017) and the entry into the reception system can take much longer (e.g. NAGA 2018) or be denied altogether.

Migrants who are re-admitted to Italy following a take-back procedure (arts. 18, 23-25, Dublin III Regulation) face similar difficulties. In this context, Italy has recorded an increasing trend of incoming Dublin procedures, with a three-fold increase in 2016 with respect to 2015 (Eurostat 2018-13). ${ }^{13}$ The evaluation is particularly lengthy, with the resulting protraction of migrants' precariousness (AAVV 2017). Adding to this, the time limits for the evaluation, as per art. 21.1 of the Dublin Regulation, often expire, with the result that migrants cannot be subject to a Dublin Procedure any longer. Attempts to overcome the deficiencies and imbalances of the Dublin Regulation have been made with the introduction of specific tools. The most well-known of these is perhaps the mechanism of relocation, which nevertheless has proved ineffective because EU member states have largely acted according to their "own interests" (see Stege 2018).

There are also migrants that are granted reception but that choose to flee. Where a voluntary and formally unjustified abandonment of reception applies, migrants are excluded from reception measures (cf. arts. 13 and 23 LD. 142/2015). This highlights the tension between the current logic underlying reception and asylum, that is, to stay in a country, and the actual condition and choice of many migrants to move across Europe.

A recent report by Médecins Sans Frontières (MSF 2018) has addressed the conditions of migrants experiencing one (or more) of the situations described above. It has underlined the "invisibility" of migrants that are barely protected by institutions and at a high risk of being forced into informal settlements in public spaces (parks, squares, railway station platforms, etc.) or squatting in abandoned buildings (compare Pogliano and Ponzo, Chap. 6 in this volume). Many of the informal settlements are found in border cities close to the Balkan route, including North-western Italian cities such as Trieste, Gorizia, Udine, but also Trento and Bolzano, further up north, as well as in Foggia and Crotone, in Southern Italy, where centres of first reception are located. Squatting is mostly evident in larger metropolitan areas. Evidence of similar circumstances, most often in the absence of institutional interventions, has been found in border locations of other EU countries, such as Calais (Rigby and Schlembach 2013; King 2016).

Various scholars have provided informed accounts of civil society actors assisting destitute migrants (on Italy: Campomori 2008; Marzorati et al. 2017; on the US: De Graauw 2015) and undocumented migrants (Ambrosini 2018) who face precarious and vulnerable conditions, and likewise migrants transiting through border areas.

\footnotetext{
${ }^{13}$ Data is available at: http://appsso.eurostat.ec.europa.eu/nui/show.do?dataset=migr dubri\&lang=en. Accessed 27 August 2018.
} 
Scholars have identified the role of civil society actors as crucial in the wider framework of the European border regime. A general attitude has been observed among government agencies of "turning a blind eye" to the presence of migrants, while delegating responsibility to the third sector (Ambrosini and Van der Leun 2015; Bonizzoni 2017; Ambrosini 2018) as, in compliance with national (excluding) norms, the state does not have to meet their needs. Some scholars criticize similar forms of delegation (Ambrosini and Van der Leun 2015; Balbo 2015; Marzorati et al. 2017; Mayblin and James 2018) by suggesting their substitute function contributes to the disengagement of the public sector (Castañeda 2007).

Generally speaking, the growing assumption that (some) migrants are "in transit" has often overshadowed the relevance of evolving migration patterns, even in urban contexts located at the crossroads of internal and international borders. What can be defined as "transit migration framework" has not only contributed to the neglect of some migrants' experiences, but has somehow legitimised nonintervention by local governments with respect to wider integration issues (Marconi 2018). This is in line with a more general tendency to consider forced migrants as a temporary population with the resulting adoption of temporary policy solutions (Fabos and Kibreab 2007). Davies et al. (2017) argue that this form of institutional abandonment can be interpreted as a means of control perpetrated through inaction. However, with the rapid diffusion of the (often blurred) "transit terminology" (e.g. transit migration, transit countries, transit migrants) in the public and political discourse, transit countries and areas have been increasingly accused of being responsible for transit migration itself. At the same time, they have been asked and induced to cooperate in filtering unwanted "inflows" of people (Düvell 2012; Düvell et al. 2014).

While this can be described as an evident manifestation of a wider migration regime, it cannot be interpreted as a set of fixed dynamics, but needs to be looked at in relation to contextual specificities, including growing concerns and emotions associated with xenophobia and racism. This is particularly true for the field of migration that has been described as very contentious (Della Porta 2018).

Additionally, as many authors have stressed, migration policies can translate into practices that, even in contradictory ways, are "less efficient" and more tolerant. Policies can be more or less coherent with respect to national legislations, and more or less inclusive with respect to migrants. Some local authorities have refused to adhere to national (exclusionary) approaches, by choosing to support irregular migrants (Varsanyi 2006; Davies et al. 2017; Ambrosini 2018); while others have shown varying degrees of willingness to grant, and difficulty in dealing with, reception for (otherwise stranded) asylum seekers (e.g. Davis et al. 2016); others still have designed interventions that reinforce the exclusionary nature of national policies (Gilbert 2009; Chand and Schreckhise 2015; Gargiulo 2017).

National governments bear the primary responsibility for immigration policy (concerning the entry of migrants and citizenship regulation), while local governments are responsible for the provision of services. Research has shown that local authorities have been prone to adopt pragmatic approaches to migrants' incorporation (Caponio and Borkert 2010; Jørgensen 2012; Marzorati et al. 2017), as they are 
faced with their needs most directly (Borkert and Bosswick 2007; Vermeulen and Stotijn 2010) and somehow are "forced" to address them in some ways (Ambrosini and Boccagni 2015). In Italy, this has been happening in a context characterised by weak regulation at the national level and strong fragmentation of institutional responsibilities (Caponio and Pavolini 2007; Balbo 2015) that has resulted in considerable local variations in the provision of services (Caponio and Campomori 2014). Furthermore, it has been adding to a welfare system that determines the eligibility of social rights depending on legal status (Sainsbury 2012), meaning access to it is most restricted to undocumented and forced migrants.

In this direction, we will look at dispersal and reception policies in Italy, and how and to what extent they have been implemented at a local level and in border localities that have been faced with the presence of migrants transiting through them. The focus will be specifically on three cities along the Brenner route: Verona, Trento and Bolzano.

\subsection{The Methodological Approach}

Our approach involves a triangulation of research techniques: legal analysis of policy documents, content analysis of nine interviews carried out with institutional and civil society actors in Verona and Trento between September 2017 and April 2018, ${ }^{14}$ and a non-systematic content analysis of newspaper articles - particularly articles referred to by interviewees, and secondary research material. This research has also benefited from discussions with volunteers of the project "Antenne Migranti", ${ }^{15}$ with whom one of the authors has been volunteering since May 2016. Discussions centred on policies implemented by institutional agents in Verona, Trento and Bolzano, as well as practices identified by volunteers by speaking to migrants and by accompanying them to helpdesks and public offices. Note that no interviews were carried out in Bolzano due to resource constraints.

\footnotetext{
${ }^{14}$ CIR employee, 9/3/2018; Operator of dorms, 4/12/2017; Don Calabria supervisor, 8/3/2018; Executive Officer Polfer 17/12/2017; Reception Office Coordinator of the Social Service Department of the Municipality of Verona, 23/3/2018; Islamic centre Board Member, 19/12/2017; Director of Cinformi, 7/3/2018; Helpdesk Operator, 18/4/2018; Soup kitchen operator, 4/5/2018.

${ }^{15}$ Antenne Migranti is a project coordinated by the Alexander Langer Stiftung Foundation, in Bolzano, with partial funding from the Open Society Foundation to support a coordinator. The project is run by volunteers and has these objectives: to detect and prevent the violation of migrants' rights along the Brenner route; to support migrants by directing them to local services and helping them with asylum procedures; to assess migrants' needs and stimulate institutions to respond to them; to promote an informed debate on reception and free movement; and to promote the development of effective trans-local networks on reception and transit.
} 


\subsection{The Case Studies}

\subsubsection{Verona}

The reception system in Verona comprises a SPRAR and a CAS system. The former comprises 97 places for beneficiaries in five projects - two for ordinary beneficiaries and three for unaccompanied minors-under the responsibility of the Municipality of Verona; ${ }^{16}$ the latter accommodates 2705 beneficiaries under the responsibility of the prefecture ${ }^{17}$ that has delegated implementation to 30 social cooperatives. Out of 98 municipalities in the wider provincial territory, only three, including the Municipality of Verona itself, have activated a SPRAR project so far.

Resistance to reception has been strong and it can be associated with political factors. The current governing coalition in Verona is led by the right-wing party Lega Nord, known in Italy for its xenophobic positions against migrants and its firm opposition to reception. Shortly after the beginning of his mandate, in May 2017, the current mayor forcefully declared his opposition to reception for migrants "who do not have the right to stay", ${ }^{18}$ but he has been silent since. The previous mayor had developed a more open attitude towards migrants, after departing from an overtly racist attitude (Semprebon 2010). At the same time, his approach was in line with his successor in that he stressed the distinction between economic migrants and "deserving" asylum seekers. ${ }^{19}$ He also called for police forces not to prevent migrants from getting on trains heading to Brenner, and for European member states to agree on the delivery of a European humanitarian permit, so that Italy was not left to deal with the phenomenon alone. ${ }^{20}$ On their side, in the most recent years, some mayors in provincial localities have openly supported the extreme-right movement "Verona ai Veronesi" (Verona to the Veronese) and its protests against reception. ${ }^{21}$

\footnotetext{
${ }^{16}$ Data (March 2018). http://www.sprar.it/progetti-territoriali?_sft_provincia=verona. Accessed 26 June 2018.

${ }^{17}$ Prefecture of Verona data, 30 November 2017.

${ }^{18}$ Verona Sera, 29 June 2017 "Profughi. Sboarina vuole cambiamenti. Ferrari: Aderisca allo Sprar". http://www.veronasera.it/cronaca/sboarina-profughi-ferrari-sprar-29-giugno-2017.html; L'Arena 27 June 2017, "Sboarina e i profughi 'Sì a chi ha diritto, no ai clandestini'”. http://www.larena.it/ territori/citt\% C3\% A0/sboarina-e-i-profughi-s\% C3\% AC-a-chi-ha-diritto-no-ai-clandestini-1.5797961. Accessed 20 June 2018.

${ }^{19}$ L'Arena, 2 February 2017 "Centro profughi Tosi perplesso: 'Meglio altrove", http://www.larena.it/territori/citt\%C3\%A0/centro-profughi-tosi-perplesso-meglio-altrove-1.5463105; Verona Sera, 3 January 2017. Protesta dei profughi a Veronetta, Tosi: "Inaccettabile. Che siano allontanati". http://www.veronasera.it/cronaca/tosi-protesta-profughi-veronetta-3-gennaio-2017.html. Accessed 20 June 2018.

${ }^{20}$ Verona In, 29 September 2015 "Tosi alla Polfer: lasciate salire i profughi sui treni”. http://www. verona-in.it/2015/09/29/tosi-alla-polfer-di-verona-lasciate-salire-i-profughi-sui-treni/. Accessed 20 June 2018.

${ }^{21}$ Verona Sera, 4 July 2017 "Anche a Roncolevà, Verona ai Veronesi contro il 'business dell'accoglienza"”. http://www.veronasera.it/cronaca/verona-ai-veronesi-trevenzuolo-4-luglio-2017.html; Verona Sera, 24 June 2017 "Presidio a Buttapietra di "Verona ai Veronesi" contro il
} 
Verona is located in the north-eastern Italian region of Veneto and is not a town of first arrival. Migrants mostly arrive here through the dispersal system operating in Italy, while some of them arrive autonomously, while transiting through the country. In fact, Verona is located at the intersection of several important transport routes: the main train station functions as an interchange for railway traffic from Bologna to Brenner, from Venice to Milan and west to Ventimiglia. It is also connected to Quadrante Europa, one of the largest freight terminals in Italy (in terms of volume).

According to the CIR employee interviewed, following the increasing enforcement of border controls at Brenner and the closure of the Balkan route towards the north, a growing number of migrants have been transiting through from the Balkans towards Italy since mid-2015. In September 2017, the local branch of CIR (Consiglio Italiano Rifugiati - Italian Council for Refugees, a national NGO specialised on asylum) estimated that a total of 50 migrants were on the waiting list to access reception (narrative evidence by a CIR employee).

CIR has been operating a legal support desk for reception beneficiaries, as a partner of the local SPRAR project. In recent years, the same desk has also been providing support to migrants that arrive autonomously in Verona. Because of increasing arrivals, funding was sought to provide them with temporary accommodation. In particular, a specific CAS was opened for this purpose, managed in collaboration with Caritas, although with a limited capacity of around 25 places - plus a few extra places in the ordinary SPRAR project, if needed (interview with CIR employee, 9 March 2018). In practice this CAS offers pre-reception accommodation for asylum seekers that arrive by land while they wait to access the reception system.

CIR is also the lead partner of a project, funded by the Ministry of Interior, for holders of subsidiary protection or refugees who are homeless and jobless. All these individuals may be potential candidates for secondary movements towards Northern Europe or France, although their legal status does not allow them to work in European countries other than that from which they have obtained international protection. Initially the helpdesk was open to holders of humanitarian protection too but it was later decided to target only migrants with a higher form of protection (no explanation for this was provided during the interview). The project involves support in the search for housing and employment (ibd.), which are often hard for reception beneficiaries to find once they have completed their reception project (see for example MSF 2017). For these migrants, if they are clearly vulnerable, some temporary accommodation (15 days) is provided by a helpdesk that manages access to the local dorms. Normally, access (or a short renewal) is requested by CIR after the migrants access their helpdesk (interview with operator of dorms, 4 December 2017). This also applies to migrants arriving autonomously on the territory, upon formalisation of their asylum application, and to migrants whose asylum application

possibile arrivo di 40 profughi". http://www.veronasera.it/cronaca/presidio-corteo-magnanoprofughi-verona-ai-veronesi-24-giugno-2017-.html. Accessed 10 July 2018. 
has been rejected and who are still homeless 1 year after completion of their reception project.

A third (already finished) project managed by CIR was specifically targeted to unaccompanied minors and was funded by the AMIF (Asylum and Migration and Integration Fund). In this project, CIR was co-partner, together with NGOs based in Gorizia, Udine, Trieste, Roma and Puglia, with the main aim of providing legal assistance to unaccompanied minors and monitoring their transit from Southern to Northern Italy, northward through borders with Austria and westward through borders with Slovenia. According to a CIR employee (9 March 2018), 30\% of the minors they assisted at their legal desk were seekers of international protection who intended to reach a relative residing in another EU country with whom they were in contact.

Verona was a transit town for most of them, which in the opinion of the CIR employee was largely due to their scarce (if any) awareness of the Dublin Regulation and their family reunion rights. This made it crucial to provide them with legal information (Koser 2010; Bloch et al. 2011), also in view of preventing potentially dangerous onward movements, for example on freight trains. Yet, lengthy procedures often meant that minors would be unwilling to wait and would decide to continue their travel on their own.

CIR has also been working in synergy with Don Calabria, a religious body that runs projects targeting vulnerable groups and individuals, including the management of a community centre for unaccompanied minors. This centre currently hosts around 30 beneficiaries, as part of one of the municipality's SPRAR projects (interview with Don Calabria Supervisor, 8 March 2018). Don Calabria has ten extra places of "pronta accoglienza" available: these are "last minute" accommodation places usually occupied by minors who are stopped by the police at the train station (or elsewhere in town) while trying to transit through the city.

Since 2014, minors have continued arriving, although an Executive Officer of Polfer, the railway police, ${ }^{22}$ stated that the transit of migrants reached a peak in $2016^{23}$ to then decrease to a few dozen after summer 2017—in line with the drop in arrivals on southern Italian shores (interview, 17 December 2017)—and that these movements have rarely involved unaccompanied minors. Possibly they have rather been less visible in Verona. We will come back to this later.

There is also an issue of misrepresentations by the media, as police forces themselves testified ${ }^{24}$ : the news repeatedly referred to migrants transiting through stations on the Brenner route, but in fact such movements often involve migrants permanently settled in Italy who regularly commute to nearby cities for work or to

\footnotetext{
${ }^{22}$ The Polfer in Verona is responsible for inspections along the Brenner railway line from Verona to Brenner.

${ }^{23}$ Around 100-150 migrants, mainly Eritreans and Syrians, between July and August.

${ }^{24}$ Corriere di Verona, 26th Jun. 2016 "Senza biglietto sul treno locale. Ma non sono profughi". https://www.pressreader.com/italy/corriere-di-verona/20160623/281711203946664. Accessed 20 June 2018.
} 
beg - as well as seekers of international protection hosted in local reception centres that go to train stations to benefit from free Wi-Fi.

Ten places for "pronta accoglienza" for unaccompanied minors have proved to be insufficient, with the result that minors have been often accommodated in centres outside Verona or even outside the region. Additionally, movements have become more complex. In the first months of 2018, reception operators started experiencing two new specific typologies: on the one side, northward arrivals from Southern Italy, following minors' flight from a reception centre - often described as being of very poor standard - with the intention of reaching a family member in Northern Europe; on the other side, southward arrivals from Germany and Sweden, following the rejection of an asylum application or the non-recognition of minors' age and the pending possibility of being deported back to their country of origin (ibd.).

In relation to the latter, the Reception Office Coordinator of the Social Service Department of the Municipality of Verona (interview, 23 March 2018), that holds the main (institutional) responsibility for unaccompanied minors, reported considerable frustration: in the face of consistent investments in time and resources (including not only accommodation but also individualised educational and employment programmes), many minors choose to leave the territory, even before completing their project. Frequently this is the consequence of a long and tiresome waiting period for the reunification procedure to be implemented.

Apart from institutional actions, some support to migrants in transit has been provided by Antenne Migranti volunteers, volunteers of the "Ronda della Carità", a mobile food service targeting homeless people that has long been active, as well as various volunteers and activists of local associations working in the field of migration and/or discrimination on an individual basis.

The local Islamic centre has been active too. As reported by a representative (interview Board Member, 19 December 2017), through word of mouth they were visited by a growing number of migrants in transit in 2015 and 2016. In particular, there were Syrians and Afghans who asked for food and money to buy a train ticket to reach Northern Europe, while more recently, the number of visitors has decreased and shifted to Senegalese and Moroccan nationals. Some migrants have asked for accommodation too, but the board decided not to provide it due to the pressure they have experienced since 2015: following the terrorist attacks in Paris, the prayer hall and the adjoined cultural centre have been under regular surveillance by police forces, with the declared purpose of protecting the Islamic community.

\subsubsection{Trento and Bolzano}

The autonomous provinces of Trento and Bolzano/Bozen (henceforth APT and APB respectively) are both situated in the autonomous region of Trentino-Alto Adige. Although the main responsibility for migration policy in Italy (i.e. control of entries, stays and returns) is in the hands of the national government, the APT and APB enjoy considerable discretionary powers in the field of migration, compared to 
ordinary provinces such as Verona, and ordinary regions such as Veneto. As a result, both autonomous provinces have adopted their own specific provincial law on migration, leading to disparities in the respective reception systems.

As early as 1990, the APT adopted provincial Law 13/1990, "Interventi nel settore dell'immigrazione straniera extracomunitaria" (Interventions in the field of non-EU migration), stating that asylum seekers and refugees are granted access to public services in the provincial territory on an equal basis with non-EU migrants. In 2002, the provincial authority adopted guidelines regulating the material conditions of reception. In the following years, subsequent protocols spelt out further specific guidelines on seekers of international protection (2003), victims of human trafficking (2003) and unaccompanied minors (2011) (interview with Director of Cinformi, 7 March 2018).

Within the same framework, the provincial authority delegated to Cinformi (Centro Informativo per l'Immigrazione - Information Centre for Immigration), an operative unit of the Dipartimento Salute e Solidarietà Sociale (Department of Health and Social Solidarity), the following activities: monitoring the presence of asylum seekers within the provincial territory; coordinating the activities of local authorities and associations in relation to immigration; providing economic assistance to asylum seekers; drafting and signing conventions with private actors providing accommodation facilities; and providing information to migrants on asylum procedures and on provincial services. ${ }^{25}$

Two decades after the approval of APT Law 13/1990, Provincial Law 12/2011 was similarly approved by the APB to regulate the integration of migrants, and seekers and holders of international protection. Additionally, as indicated by the Director of Cinformi (7 March 2018), both provinces signed a protocol ${ }^{26}$ with their respective commissaries, ${ }^{27}$ which increased their margin of manoeuvre over the management of reception policies: differently from ordinary provinces, both the APT and the APB can decide where reception centres should be located and how to distribute reception applicants accordingly.

The reception system in Trento comprises a SPRAR and a CAS system, both coordinated by the Provincial Authority. The former comprises 149 places in two projects (June 2018), one for ordinary beneficiaries and one for unaccompanied minors, under the responsibility of the Provincial Authority of Trento; ${ }^{28}$ the latter accommodates 1494 beneficiaries (August 2018), mostly of Nigerian, Pakistani, Malian, Gambian and Senegalese nationality, in 229 structures in 70 out of 72 municipalities of the provincial territory (Cinformi, May 2018). ${ }^{29}$

\footnotetext{
${ }^{25}$ For further details see http://www.cinformi.it/

${ }^{26}$ The protocol of the APT is available at: http://www.prefettura.it/FILES/AllegatiPag/1229/1_ Protocollo_d-intesa_2_aprile_2014.pdf Last accessed: 27th Jul. 2018; the protocol of the APB could not be retrieved.

${ }^{27}$ These have an equivalent function to the prefectures in ordinary provinces.

${ }^{28}$ Data (March 2018). http://www.sprar.it/progetti-territoriali?_sft_provincia=trento. Accessed 26 June 2018.

${ }^{29}$ Data (March 2018). http://www.cinformi.it/index.php/it/news_ed_eventi/archivio_news/ anno_2017/cruscotto_statistico_accoglienza/(offset)/0/(limit)/4/(sb)/312. Accessed 27 July 2018.
} 
In the APB, discussions on joining the SPRAR have been ongoing since 2017, but municipalities have only recently started activating the first projects. At the moment, beneficiaries are accommodated in six ordinary SPRAR projects, with a total of 223 places, all located outside Bolzano, ${ }^{30}$ and in various CAS structures with a total of 636 places. Narratives by Antenne Migranti volunteers reported on declarations by the mayor of Bolzano, stating he refused to join the network unless the number of asylum seekers in Bolzano diminished and reached the quota set by the Ministry of Interior (fieldwork note, 30 November 2017).

An increasing number of municipalities in the provincial territory have been providing places. This is unsurprising as, according to the 2018 Agreement on local finance, ${ }^{31}$ the Provincial Authority will not consider any request for public funds for municipalities that fail to accomplish their reception obligations set by the Provincial Authority itself. ${ }^{32}$

Similarly to Verona, considerable resistance to reception has grown in Trento and Bolzano. Various protests have been repeatedly organised by extreme-right movements and violent attacks have also taken place (although not always claimed by a specific movement). ${ }^{33}$ In the wider political context, the increasing success of the Lega Nord (now Lega), for example in municipal elections in Trento and Bolzano, must also be acknowledged. According to some political commentators, drawing from the trend in local elections, this is a sign that the autonomous Region of Trentino Alto-Adige is experiencing political dynamics that are closer and closer to those of the rest of the country and most specifically to those of the neighbouring Veneto and Lombardia regions, in spite of a decade of centre-left government. ${ }^{34}$

The APT can be described as a transit area, since it is located along the Brenner route, although its relevance in this sense seems to be less evident than for Bolzano, as we shall explain. According to estimates, approximately 20 to 30 migrants arrive autonomously in the territory every month (interview with Director of Cinformi, 7 March 2018).

A helpdesk is operated by the non-profit association Centro Astalli, which has been delegated by Cinformi to manage SPRAR projects. The helpdesk provides all asylum seekers with basic information on the asylum procedure and reception, thus

\footnotetext{
${ }^{30}$ Data (March 2018). http://www.sprar.it/progetti-territoriali?_sft_provincia=bolzano. Accessed 26 June 2018.

${ }^{31}$ Cf. Accordo sulla finanza locale per l'anno 2018, 22.12.2017. http://www.provincia.bz.it/entilocali/download/2018_Accordo_finanza_locale.pdf. Accessed 4 July 2018.

${ }^{32}$ Both provinces should accommodate no more than $0.9 \%$ of asylum seekers (in relation to the total resident population).

${ }^{33}$ Il Dolomiti, 10 April 2018 "Attentato incendiario contro il B\&B che ospiterà i profughi" Available at: http://www.ildolomiti.it/cronaca/2018/attentato-incendiario-contro-il-bb-che-ospitero-i-profughi-i-sindacati-accogliere-chi; Il Giornale dell'Alto Adige, 13 July 2017 "Centinaia di nuovi profughi in Trentino Alto Adige: CasaPound protesta con 50 striscioni sull'A22". http:// www.ilgiornoaltoadige.it/?p=76264. Accessed 7 July 2018.

${ }^{34}$ Trentino, 7th Mar. 2018 "Il voto dice che l'anomalia trentina è finita. E 1'Alto Adige si allontana" Available at: http://www.giornaletrentino.it/blog/il-voto-dice-che-l-anomalia-trentina-\%C3\%A8finita-e-1-alto-adige-si-allontana-1.1536736 Last accessed: 8th Jul. 2018
} 
also assisting migrants arriving autonomously. In 2017, approximately 400 migrants approached the desk autonomously to apply for asylum and to enter reception (interview with helpdesk operator, 18 April 2018). It was also stated that the Provincial Authority intended to improve the support, in terms of providing information and assistance, to migrants arriving autonomously, thanks to a specific economic contribution delivered by the national government to the Municipality of Trento and other municipalities in the provincial territory. ${ }^{35} \mathrm{~A}$ first contribution was given in 2017. In this second round, the Provincial Authority has expressed willingness to sign a protocol with all the municipalities that have received this contribution, in order to define a strategic plan for the most effective use of resources ${ }^{36}$ (ibd.).

Out of 400 applicants indicated above, approximately 150 eventually entered a reception project in 2017-18, after a waiting period of 2 or 3 months. According to an estimate by volunteers of Antenne Migranti, who collaborate with local volunteers engaged in a support service for homeless people, approximately 50 migrants are currently stranded on the streets (fieldwork note, 7 May 2018). While data has not been collected systematically, it can be hypothesized that half of the applicants actually leave the territory, while the other half decide to remain, possibly because of a higher scarcity of resources.

Since the increase of police controls at the Brenner border in 2016 (following declarations by the Austrian Ministry of Interior on a "clampdown" on migration), the operators of Cinformi have repeatedly collected narratives by applicants describing Milan as the actual transit spot where, in agreement with compatriots (probably acting as passeurs), migrants can be driven out of Italy across the border with Austria. Trento, as a transit spot, did not emerge clearly in this picture.

At the same time, the operator interviewed reported a peculiarity of the Brenner border. Since 2015, some "fluidity" has become evident: migrants are not always subject to police controls on the Austrian side of the border and are often left free to cross southward to reach Italy, while controls in the opposite direction have been much more systematic and have mostly resulted in migrants being stopped and asked to take the train back southward. A similar attitude was reported by police forces in Bolzano with the hypothetical result that migrants eventually arrive in Trento, the first large town south of Bolzano, but according to volunteers of Antenne Migranti this has not been happening since November 2017 (fieldwork note, 20 August 2018).

The typologies of migrants' journeys have considerably evolved over time to become more and more complex. At present, the majority of migrants who arrive autonomously in Trento had their application previously rejected in one or two

\footnotetext{
${ }^{35}$ This contribution corresponds to 500 euros for each reception beneficiary and is given to municipalities in Italy to compensate for the burden of reception, whenever they host a given percentage of asylum seekers.

${ }^{36}$ Giornale Trentino, 25 January 2018 "Arriva il bonus ai comuni: per ogni profugo 500 euro". http://www.giornaletrentino.it/cronaca/trento/arriva-il-bonus-ai-comuni-per-ogni-profugo-500euro-1.1502151. Accessed 4 July 2018.
} 
European Union countries-mainly Germany, Austria or France (interview with helpdesk operator, 18 April 2018) — and then applied for protection in Italy. Although in these cases a take-back request should be lodged as per art. 18.1(d) of the Dublin Regulation, Italy has often ended up becoming the Member State responsible, due to lengthy bureaucratic procedures. ${ }^{37}$ Furthermore, other categories of migrants approach the helpdesk, ${ }^{38}$ although not all are granted access to reception, based on rules defined in LD. 142/2015 but also by the Commissary.

Helpdesk operators help to fill in applications for reception and for asylum application appointments at the Commissary (interview with helpdesk operator, 18 April 2018). However, as Antenne Migranti volunteers have testified (fieldwork note, 6 July 2018), there are no clear, transparent rules on who is admitted to reception. The decision is up to the Commissary, with a level of discretion that seems to go beyond interpretation of the asylum norm. An example of non-transparent and unclear rules, as reported by volunteers themselves, are those that apply to migrants who have already applied for asylum in another Italian city. In this case the underlying assumption is that each locality has the capacity to host applicants, hence they all have a chance to enter the system. This is actually consistent with LD. 142/2015. However, consistency is less obvious in the case of vulnerable applicants, and yet this decree still does not ensure their access to reception. Antenne Migranti volunteers reported that access had been recently denied to migrants re-admitted to Italy regardless of obligations set by the Dublin Regulation (art. 18), or of any form of vulnerability suffered by the applicants (fieldwork note, 4 May 2018).

It is questionable whether this recent filter has been applied to address the local administrators' fear of a "pull effect", possibly associated with a word-of-mouth narrative among migrants suggesting that Trento is more welcoming than nearby cities, in particular Bolzano, which has severely restricted access to the reception system with the introduction of the Circolare Critelli (circular letter) as will be explained below. It is legitimate to wonder whether the Provincial Authority in Trento may have somehow "emulated" the approach adopted in Bolzano to avoid an extra "burden" of reception resulting from the restrictions introduced by the Circolare.

Concern about an extra "burden" has also been stated explicitly, in a recent press release, ${ }^{39}$ whereby the President of the Provincial Authority of Trento (together with that of the Provincial Authority of Bolzano) has taken a strong stance with the Ministry of Interior, calling for indications on how to include migrants that arrive autonomously in the national system of dispersal, and on whether resources for

\footnotetext{
${ }^{37}$ Cf. art. 23.3 and 29.2, Regulation 604/2013

${ }^{38}$ These include: migrants arriving from southern Italy who have abandoned or have been expelled from a reception centre in another Italian city, where they have a pending appeal; holders of international protection that are stranded without a house and job; migrants who upon arrival on southern Italian shores get into contact with smugglers to be driven up north; but also migrants from Colombia and Ukraine who arrive on a tourist visa and then apply for asylum.

${ }^{39}$ Press Release 1546, Autonomous Province of Trento, 21 June 2018 "Richiedenti asilo, dalla Conferenza Regioni ok alla proposta del Trentino e dell'Alto Adige."
} 
homeless people should also be used for them (and for migrants that terminate their reception project or for whom reception measures are withdrawn, thus making them homeless).

Resources for homeless people are a thorny issue. Access to food distribution is open to everyone but operators insist on the need to improve collaboration with social services and operators dealing with reception. They have lamented the fact that they have had to use homelessness resources for asylum seekers, while they should be dealt with by Cinformi, Astalli and municipal social services, not least given their specific skills in addressing the needs and vulnerabilities of asylum seekers (Soup kitchen operator, 4 May 2018).

Access to dorms is regulated thorough a helpdesk operated by five local associations. While they used to be fully accessible to everyone, increasingly restrictive rules have been introduced, emulating the approach of Verona, and then revised again. Currently, people that have a residency status in Trento can stay in the dorms for 30 plus 30 days, while those with no residency status can only stay for 30 days (both with a possible renewal of 30 days).$^{40}$ The most crucial issue around permanence has concerned the limited time allowed, with the result that many people, including asylum seekers that arrive autonomously, fall into homelessness for up to four or 5 months even after they have formalized their application for asylum which is why temporary accommodation solutions were found in winter 2017. It also concerns the fact that, similar to Verona (fieldwork note, 9 March 2018), it often takes more than a month for asylum seekers to formalize their asylum application and that formalization requires, among other things, a letter stating their domicile. This can only be provided by dorms during the time they host people. In turn, this has contributed to creating a "black market" for asylum seekers that need to buy a letter from friends or compatriots (Soup kitchen operator, 4 May 2018; and for Verona fieldwork note, 9 March 2018).

As explained by the helpdesk operator interviewed, whenever a homeless vulnerable migrant approaches the helpdesk (or a migrant completes his/her reception project and becomes homeless), an application for reception is forwarded to the SPRAR. As set out by LD. 142/2015, the specific situation and needs of vulnerable persons must be taken into account (including minors, disabled people, elderly people, pregnant women, single parents with children who are minors, victims of human trafficking, people with serious illnesses, people with mental disorders and people who have been subjected to torture, rape or serious forms of psychological, physical or sexual violence). Yet, available places in SPRAR are very limited and most often it is local associations that provide for them, with temporary accommodation paid by the Provincial Authority.

Similarly to the APT, in the APB the Provincial government coordinates the reception system and since mid-2017 has delegated implementation to the following

\footnotetext{
${ }^{40}$ Regolamento e criteri di gestione dello sportello unico per l'accoglienza delle persone senza fissa dimora (Rules and criteria for the management of the helpdesk for the reception of homeless people), provided by soup kitchen operator (updated 4 December 2017).
} 
actors: the NGO Associazione Volontarius Onlus, together with the social cooperative River Equipe, Caritas, the Red Cross, and SPES srl Social Enterprise.

Considering its geographical and strategic position - it is along the Brenner railway route and de facto the last large city before the Brenner Pass - Bolzano (and its provincial area) can also be considered a transit area for migrants. It has become a transit zone, a sort of internal hotspot, following the increasing controls carried out at Brenner and in Bolzano, as a result of the agreements cited in the introduction (see notes 2, 3, 4) that have de facto forced migrants stopped at Brenner to return to Bolzano.

As in Trento and Verona, some migrants arrive autonomously in the town, particularly from Nigeria, Ghana, Gambia, Mali, Senegal, Iraq, Pakistan and Afghanistan. At the end of June 2017, a total of 146 male migrants were recorded as being present (Antenne Migranti and ASGI 2017).

For such migrants, access to reception has been limited since the approval of the aforementioned Circolare Critelli from the Provincial Authority, dated 27 September 2016, although even earlier it was very much restricted. This circular spells out the categories of migrants who cannot access reception, in particular: migrants who have right to relocation, male parents of minors of less than 14 years old (at the beginning of October 2016 the age was raised to 18), and migrants who have stayed in a European or non-European country or in an Italian region (and did not just transit through). What is more is that as far as vulnerable individuals are concerned, there is no specific provision for access even if they fall under any of these categories. Their needs are taken into consideration only in exceptional circumstances (e.g. certified severe health problems) and if they are clearly in transit (i.e. if they are stopped by the police at the border). In any of these cases, access is only considered for a maximum of 3 days. Contrary to what happens in Trento, no application is made for entrance into SPRAR projects, as these individuals are de facto considered as "fuori quota" (that is to say, arriving asylum seekers who take the numbers above the quota assigned to the Province of Bolzano by the Ministry of Interior). As a result of this, at the end of June 2018, around 260 people were homeless on the streets (160 in families and 100 single people), according to estimates collected by Antenne Migranti volunteers through Caritas (fieldwork note, 27 June 2018).

Migrants that cannot enter the reception system are basically left homeless and they only have access to two free meals per day-following insistence on the side of Antenne Migranti for a minimum of two meals to be given to them in the local soup kitchen operated by Caritas for homeless people-and one free shower per week. This scenario hit the headlines in 2017, when the news reported about Adan, a 13 year old who in spite of having muscular dystrophy was still left out on the streets with his family and eventually died a few days later. ${ }^{41}$

It should be noted that in order to meet migrants' basic needs during their stay in Bolzano, or at the actual Brenner border, two support centres were opened in 2015 at the respective train stations, which are operated by local humanitarian volunteers.

\footnotetext{
${ }^{41}$ Alto Adige, 12th October 2017 "Circolare Critelli, raccolta firme per abolirla". http://www.altoadige.it/cronaca/bolzano/circolare-critelli-raccolta-firme-per-abolirla-1.1343670. Accessed 3 May 2018.
} 
The local association Volontarius Onlus operates two support centres-one at the train station in Bolzano (since April 2015) and one at Brenner (since December 2014) — to provide basic information, food and clothing, using volunteers from a range of local third sector organisations (including local cooperatives, Caritas, the Italian Red Cross and the Alexander Langer Foundation). ${ }^{42}$ At Brenner they also coordinate an accommodation structure. Furthermore, some local parishes give shelter-although they have limited capacity and resources — and Antenne Migranti volunteers provide basic information on local services and on the asylum procedure ${ }^{43}$.

\subsection{Discussion and Final Remarks}

What actors provide what services for migrants transiting along the Brenner route? In each of the cities analysed services are limited and access restricted. Migrants that transit through cities and border areas are treated as "second-class citizens", compared to migrants arriving by sea on southern Italian shores and dispersed through the quota system. Yet, the number of autonomous arrivals has been quite stable in recent years, and it has been most problematic in Bolzano where the reception system is still under construction.

Against this scenario, our contribution has looked at the Brenner route area in order to dig out any specific elements, in terms of governance approach and configurations, that could be associated with the cities selected for the analysis and their (geographical) closeness to the border. Indeed, some common elements, as well as differences, have emerged.

First, in all three cities there are hardly any dedicated services for migrants transiting through cities and border areas. The few services available to them are relatively recent and (tend to) overlap with services for homeless people. Accordingly, criticism has been voiced by various actors about an improper use of (targeted) resources and a lack of specific professional skills to deal with this complex category of users.

Additionally, no form of collaboration exists across the three cities in dealing with migrants transiting through cities and border areas, but examples of "policy emulation" are manifest in Trento, with respect to Bolzano, and also to Verona, although only in the replication of exclusionary rather than inclusionary solutions. This could sound surprising when recalling that Trento has for a long time been considered as a "positive example" of reception, first and foremost given the prominent coordinating role of the Provincial Authority.

Second, services in Bolzano are provided mostly by third sector organisations, thus confirming their substitution function with respect to the public sector. In

\footnotetext{
${ }^{42} \mathrm{See}$ https://www.volontarius.it/assistenza-umanitaria-alla-stazione-di-bolzano/. Accessed 20 June 2018.

${ }^{43}$ See supra note 17.
} 
Trento and Verona institutional arrangements have also emerged, in more recent times, in line with the pragmatic stance, according to which local institutions cannot avoid dealing with, or at least addressing, migrants' presence. Nevertheless, particularly in Verona, services are strongly connected to actors' fundraising skills. These have taken the shape of inclusionary but also exclusionary initiatives, with an opaque tendency towards a "laissez-passer" approach. Paradoxically, in contexts such as Bolzano, it is precisely this tendency that result in forms of containment for migrants getting stuck in the city when sent back from Brenner.

Third, this chapter shows that restricted access to reception is not always justified on the basis of the asylum policy. Restriction criteria are spelt out by policy-makers in Bolzano and in the Circolare Critelli, in line with what has been happening elsewhere in Italy, where the majority of migration policy acts have taken the form of administrative acts; while in Trento and Verona, volunteers have reported cases of exclusion that are harder to compare with elsewhere, because they are the result of non-written decisions.

In terms of governance, this points to the fact the traditional distinction between migration policy (focused on entry and citizenship) and immigrant (integration) policy (focused on local inclusion) is somehow becoming inadequate (see Barberis and Violante 2013, and for examples in this sense, particularly with reference to residency status: Gilbert 2009; Lebuhn 2013; Gargiulo 2017). This suggests the necessity of exploring the dynamics associated with the rescaling of responsibilities across government levels in more detail (Brenner 2004), as responsibility for reception seems to be more and more rescaled down to local authorities. In turn, this will inform scholars about the evolution of the European border regime.

Fourth, restrictions for access to reception are even more problematic for migrants that are especially vulnerable, although the national and European normative frameworks stress their specific needs should be addressed. Actions and protests have been organised by activists in all three cities, and migrants themselves, to put forward their claim for protection.

The overall aim behind policies and practices addressing migrants in transit in the three cities is clearly to limit access as much as possible to "repel any extra burden" while preventing any potential "pull effect", linked to restrictive policies of neighbouring cities.

That being said, what are the factors that explain the specificities of the reception systems of Verona, Trento and Bolzano, as illustrated above?

The geographical positioning is partly predictive of the categories of migrants that can arrive on the territory. All three cities are quite far from Brenner and yet they are situated in the wider railway route area and have been affected by increasing internal border controls, which have transformed them into internal hotspots, as mostly evident in Bolzano. Hence, these localities have had to respond somehow to the presence of migrants that are transiting through cities and border areas.

Another factor is political in nature. Municipal and provincial authorities have been under pressure not to welcome migrants arriving outside of the ordinary 
dispersal system. In this regard, European asylum policies certainly play a crucial role, particularly in terms of the following issues: the increasing closure of some internal borders; the more and more evident inadequacy of the Dublin Regulation; the flights of unaccompanied minors from centres in Verona; and the (still) timid cooperation on relocation among EU member states, as recently emerged at the EU summit on migration ${ }^{44}$, which is one of the main causes of the failure of the relocation mechanism.

Reflections on migrants that are transiting through cities and border areas and more generally on effective access to reception and protection for forced migrants are particularly crucial, with reform of the whole EU common asylum system still under discussion. The call for a solid European policy is manifest in the positions expressed by various institutional actors on a number of occasions. Nevertheless, their positions appear to be rather instrumental to prove to their voters the supposed unwillingness and inability of the EU to manage migration. In fact, this desired reform has periodically hit the headlines but, de facto, has remained no more than talk for a long time. Irrespective of the outcome(s) of the reform process, any change promoting the inclusion and protection of migrants that transit through cities and border areas remains unlikely. This is all the more evident for Italy, following the recent coming into force of what is known as the Salvini Decree in December 2018.

While this Law is coherent with a more general long-term policy approach based on emergency and the marginalisation of forced migrants (see Marchetti 2012), it has introduced elements that are likely to contribute to an increase of their marginality. The humanitarian protection status has been almost abolished, being partly "substituted" by the so-called permits for "special cases". Limits have been introduced for access to residency status (the permit to stay for asylum application is no longer considered as a valid document for residency application) that de facto legitimize on-going practices of exclusion on the side of local authorities. ${ }^{45}$ SPRAR is only accessible to refugees and holders of subsidiary protection, which again legitimizes an ongoing practice. ${ }^{46}$

Another important consideration must be made in terms of policy and governance more generally. It is evident that the category "migrants in transit" includes migrants with different legal statuses, migration journeys and projects. It is equally evident that it is a category that has been constructed through policies and the devel-

\footnotetext{
${ }^{44}$ Espresso, 29 June 2018 "Vertice UE sui migranti, ecco il testo dell'accordo: parola chiave è "base volontaria". http://espresso.repubblica.it/palazzo/2018/06/29/news/ue-e-migranti-ecco-iltesto-dell-accordo-la-parola-chiave-e-base-volontaria-1.324457 . Accessed 29 June 2018.

${ }^{45}$ Consoli D. and Zorzella N. "L'iscrizione anagrafica e l'accesso ai servizi territoriali dei richiedenti asilo ai tempi del salvinismo", 8 January 2019. https://www.asgi.it/asilo-e-protezione-internazionale/liscrizione-anagrafica-e-laccesso-ai-servizi-territoriali-dei-richiedenti-asilo-aitempi-del-salvinismo/ Accessed 3 March 2019.

${ }^{46}$ Pepino L. "Le nuove norme su immigrazione e sicurezza: punire i poveri”, 20 December 2018. https://www.asgi.it/asilo-e-protezione-internazionale/le-nuove-norme-su-immigrazione-esicurezza-punire-i-poveri/ Accessed 3 March 2019.
} 
opment of a specific and yet blurred terminology of "transit migration". Focusing the analysis further on the actual experience of this category of migrants carries the risk of re-instating it, while also moving attention away from the fact that such categorization has been produced with the aim of "fixing" positions and entitlements (Zetter 2007).

Dispersal locations, in particular those in border areas, have become veritable internal borders (Fontanari and Borri 2017) where local processes of bordering take place (Lebuhn 2013). Such processes have de facto reinforced entry regulations associated with immigration policy, resulting in new borders at the local level. Interestingly, many forced migrants are not calling for the right to enter and stay but rather for the "right to come and go" (Fernandez and Olson 2011: 415). This calls for more attention not only to issues of presence, but also of mobility, as underlined by critical migration and border scholars (see for example Mezzadra and Neilson 2016).

Such an approach promises to inform the wider literature on migration and forced migration governance and to put under discussion systems based on the principle of universal residence-based welfare, a principle that is more and more evidently excluding (Könönen 2018). It promises to provide insights into the re-elaboration of a welfare model capable of addressing the right to mobility for all and the need to overcome the tendency to implement "sedentary" policy solutions to address policy fields, such as that of migration, that are by definition fluid.

\section{References}

AAVV. (2017). Rapporto sulla protezione internazionale in Italia. http://www.sprar.it/ pubblicazioni/rapporto-sulla-protezione-internazionale-in-italia-2017

Accardo, Y., \& Guido, G. (2016). Accogliere: la vera emergenza. http://www.lasciatecientrare.it/ j25/attachments/article/193/lasciateCIEntrare\%20rapporto\%202016-2.pdf

Accorinti, M. (2015). Centri di accoglienza: varietà tipologia e dibattito collegato. Rivista delle Politiche Sociali, 2-3, 179-200.

Agier, M. (2005). Ordini e disordini dell'umanitario. Dalla vittima al soggetto politico. Antropologia, 5(5), 49-65.

Ambrosini, M. (2018). Irregular Immigration in Southern Europe. Actors, dynamics and governance. Cham: Palgrave Macmillan.

Ambrosini, M., \& Boccagni, P. (2015). Urban multiculturalism beyond the "backlash". New discourses and different practices in immigrant policies across European cities. Journal of Intercultural Studies, 36(1), 35-53.

Ambrosini, M., \& Marchetti, C. (2008). Cittadini possibili. Un nuovo approccio all'accoglienza e all'integrazione dei rifugiati. Milano: Franco Angeli.

Ambrosini, M., \& Van der Leun, J. (2015). Introduction to the special issue: Implementing human rights: Civil society and migration policies. Journal of Immigrant and Refugee Studies, 13(2), $103-115$.

Antenne Migranti, \& ASGI. (2017). Lungo la rotta del Brennero. Rapporto di monitoraggio sulla situazione dei migranti a Bolzano e al Brennero. https://www.asgi.it/wp-content/ uploads/2017/09/2017_Report_Monitoraggio_Bolzano_Brennero_25_09.pdf.

Balbo, M. (2015). Migrazioni e piccoli comuni. Milano: Franco Angeli. 
Barberis, E., \& Violante, A. (2013). Rescaling, governance e frammentazione territoriale delle politiche dell'immigrazione: il caso della segregazione scolastica. In Y. Kazepov \& E. Barberis (Eds.), Il welfare frammentato (pp. 107-123). Rome: Carocci Editore.

Bloch, A. (2008). Refugees in the UK labour market: The contention between economic integration and policy-led labour market restriction. Journal of Social Policy, 37(1), 21-36.

Bloch, A., Sigona, N., \& Zetter, R. (2011). Migration routes and strategies of young undocumented migrants in England: A qualitative perspective. Ethnic and Racial Studies, 34(8), 1286-1302.

Bonizzoni, P. (2017). The shifting boundaries of (un)documentedness: A gendered understanding of migrants' employment-based legalization pathways in Italy. Ethnic and Racial Studies, 40(10), 1643-1662.

Borkert, M., \& Bosswick, W. (2007). Migration policy-making in Germany: Between national reluctance and local pragmatism? (IMISCOE working paper 20). Amsterdam: IMISCOE.

Boswell, C. (2001). Spreading the costs of asylum seekers: A critical assessment of dispersal policies in Germany and the UK. London: Anglo-German Foundation for the Study of Industrial Society.

Brenner, N. (2004). New state spaces: Urban governance and the rescaling of statehood. Oxford: Oxford University Press.

Campesi, G. (2011). The Arab Spring and the Crisis of the European Border Regime: Manufacturing emergency in the Lampedusa Crisis (EUI working papers, RSCAS, 2011(59)). http://cadmus. eui.eu/handle/1814/19375

Campomori, F. (2008). Immigrazione e cittadinanza locale: La governance dell'integrazione in Italia. Roma: Carocci.

Caponio, T., \& Borkert, M. (2010). The local dimension of migration policymaking. Amsterdam: Amsterdam University Press.

Caponio, T., \& Campomori, F. (2014). Migrant reception policies in a multilevel system: Framing and implementation structures in the Italian regions. In E. Hepburn \& R. Zapata-Barrero (Eds.), The politics of immigration in multilevel states (pp. 130-149). Basingstoke: Palgrave Macmillan.

Caponio, T., \& Pavolini, E. (2007). Politiche e pratiche di gestione dei fenomeni migratori. Mondi Migranti, 3/2007, 23-29.

Carta di Roma. (2017). Notizie da paura. Quinto rapporto Carta di Roma. https://www.cartadiroma.org/wp-content/uploads/2017/12/Rapporto-2017-Notizie-da-paura.pdf. Accessed 28 Mar 2018.

Casolari, F. (2016). The EU's hotspot approach to managing the migration crisis: A blind spot for international responsibility? Italian Yearbook of International Law Online, 25(1), 109-134.

Castañeda, H. (2007). Paradoxes of providing aid: NGOs, medicine, and undocumented migration in Berlin. $\mathrm{PhD}$ dissertation, University of Arizona.

Chand, D. E., \& Schreckhise, W. D. (2015). Secure communities and community values: Local context and discretionary immigration law enforcement. Journal of Ethnic and Migration Studies, 41(10), 1621-1643.

Ciabarri, L. (2015). Corridoi migratori via mare verso l'Italia. In B. Pinelli \& L. Ciabarri (Eds.), Dopo l'approdo. Un racconto per immagini e parole sui richiedenti asilo in Italia (pp. 87-110). Firenze: Edit.

Dal Zotto, E. (2014). Frame dell'emergenza e migrazioni forzate. Il caso dell'Emergenza Nord Africa. In P. Musarò \& P. Parmiggiani (Eds.), Media e migrazioni. Etica, estetica e politica del discorso umanitario (pp. 125-138). Roma: Franco Angeli.

Darling, J. (2016). Asylum in austere times: Instability, privatisation, and experimentation within the UK asylum dispersal system. Journal of Refugee Studies, 29(4), 483-505.

Davies, T., Isakjee, A., \& Dhesi, S. (2017). Violent inaction: The Necropolitical experience of refugees in Europe. Antipode, 49(5), 1-22. 
Davis, M. F., Oomen, B., \& Grigolo, M. (2016). Global urban justice: The rise of human rights cities. Cambridge: Cambridge University Press.

Della Porta, D. (2018). Solidarity mobilizations in the 'refugee crisis': Contentious moves. Cham: Palgrave Macmillan.

Denaro, C. (2016). Agency, resistance and (forced) mobilities. The case of Syrian refugees in transit through Italy. Revista Interdisciplinar da Mobilidade Humana, 24(47), 77-96.

De Graauw, E. (2015). Polyglot Bureaucracies: Nonprofit advocacy to create inclusive city governments. Journal of Immigrant and Refugee Studies, 13(2), 156-178.

Düvell, F. (2012). Transit migration: A blurred and politicised concept. Population, Space and Place, 18(4), 415-427.

Düvell, F., Molodikova, I., \& Collyer, M. (Eds.). (2014). Transit migration in Europe. Amsterdam: University Press.

European Commission. (2015). Statement following the temporary reintroduction of border controls by Austria, particularly at the Hungarian-Austrian border, 15/5648, 15 September 2015. http://europa.eu/rapid/press-release_STATEMENT-15-5648_en.htm

Fabos, A., \& Kibreab, G. (2007). Urban refugees: Introduction. Refuge, 24, 3-10.

Fernandez, L., \& Olson, J. (2011). To live, love and work anywhere you please: Critical exchange on Arizona and the struggle for locomotion. Contemporary Political Theory, 10, 415-417.

Fontanari, E., \& Borri, G. (2017). Civil society on the edge: Actions in support and against refugees in Italy and Germany. Mondi Migranti, 3, 23-51.

Gargiulo, E. (2017). The limits of local citizenship: Administrative borders within the Italian municipalities. Citizenship Studies, 21(3), 327-343.

Gilbert, L. (2009). Immigration as local politics: Re-bordering immigration and multiculturalism through deterrence and incapacitation. International Journal of Urban and Regional Research, $33,26-42$.

Griffiths, D., Sigona, N., \& Zetter, R. (2005). Refugee community organisations and dispersal: Networks, resources and social capital. Oxford: Policy Press.

Hein, C. (2010). Rifugiati. Vent'anni di storia del diritto d'asilo in Italia. Roma: Donzelli.

IntegrAzione. (2012). I rifugiati invisibili. L'integrazione informale nella Capitale. http://www. meltingpot.org/IMG/pdf/I_rifugiati_invisibili.pdf.

Jørgensen, M. (2012). The diverging logics of integration policy making at national and City level. International Migration Review, 46(1), 244-278.

Kasparek, B. (2016). Routes, corridors, and spaces of exception: Governing migration and Europe. Near Futures Online. http://nearfuturesonline.org/ routes-corridors-and-spaces-of-exception-governing-migration-and-europe/

King, N. (2016). No Borders - The politics of immigration control and resistance. London: Zed Books.

Könönen, J. (2018). Differential inclusion of non-citizens in a universalistic welfare state. Citizenship Studies, 22(1), 53-69.

Koser, K. (2010). Dimensions and dynamics of irregular migration. Population, Space and Place, 16(3), 181-193.

Lebuhn, H. (2013). Local border practices and urban citizenship in Europe: Exploring urban borderlands. City, 17, 37-51.

Marchetti, C. (2012). Framing emergency. Italian response to 2011 (forced) migrations from Tunisia and Libya. Paper presented at the "Rsc 30th anniversary conference: Understanding global refugee policy", Oxford, 6-7 December 2012.

Marchetti, C. (2016). Le sfide dell' accoglienza. Passato e presente dei sistemi istituzionali di accoglienza per richiedenti asilo e rifugiati in Italia. Merdiana, 86, 121-143.

Marconi, G. (2018). Local impacts of the Global North's blackmail concerning transit migration: The cases of Tijuana and Istanbul. In T. Caponio, P. Scholten, \& R. Zapata-Barrero (Eds.), The Routledge Handbook of the Governance of Migration and Diversity in Cities (pp. 353-363). 
Marzorati, R., \& Semprebon, M. (2018). L'accoglienza di richiedenti asilo e rifugiati in Italia. Enti pubblici e società civile tra forme di resistenza ed inclusione attiva. In AAVV. Mind the gap. Il distacco tra politiche e città. III Rapporto città - urban@it, Balducci A. et al. https://www. urbanit.it/wp-content/uploads/2017/10/Sintesi_del_Rapporto_2017.pdf

Marzorati, R., Semprebon, M., \& Bonizzoni, P. (2017). Piccolo è bello? Governare l'immigrazione nei piccoli comuni lombardi, as part of the Special Issue Mondi Migranti 1/2017, 113-130.

Mayblin, L., \& James, P. (2018). Asylum and refugee support in the UK: Civil society filling the gaps? Journal of Ethnic and Migration Studies, 45(3), 1-20.

Médecins Sans Frontières. (2018). Fuori Campo. Richiedenti asilo e rifugiati in Italia: insediamenti informali e marginalità sociale. https://fuoricampo.medicisenzafrontiere.it/Fuoricampo2018. pdf.

Mezzadra, S., \& Neilson, B. (2016). Border as method or, the multiplication of labor. Durham: Duke University Press.

Morano-Foadi, S. (2017). Solidarity and responsibility: Advancing humanitarian responses to EU migratory pressures. European Journal of Migration and Law, 19(3), 223-254.

Morris, L. (2002). Britain's asylum and immigration regime: The shifting contours of rights. Journal of Ethnic and Migration Studies, 28(3), 409-425.

NAGA. (2018). (Stra)odinaria accoglienza. Indagine sul sistema di accoglienza dei richiedenti asilo a Milano e provincia. http://www.naga.it/tl_files/naga/comunicati/(Stra)ordinaria\%20 accoglienza.pdf.

Penasa, S. (2017). L'accoglienza dei richiedenti asilo: sistema unico o mondi paralleli? Diritto Immigrazione Cittadinanza, 1, 1-25.

Rigby, J., \& Schlembach, R. (2013). Impossible protest: Noborders in Calais. Citizenship Studies, $17(2), 157-172$.

Robinson, V., Anderson, R., \& Musterd, S. (2003). Spreading the burden. Oxford: Policy Press.

Sainsbury, D. (2012). Welfare states and immigrant rights: The politics of inclusion and exclusion. Oxford: Oxford University Press.

Scalettaris, G. (2007). Refugee studies and the international refugee regime: A reflection on a desirable separation. Refugee Survey Quarterly, 26(3), 36-50.

Scannavini, K. (2010). Un Team per l'integrazione: viaggio nel mondo dell'asilo. Rapporto di Ricerca conclusivo del progetto "TEAM INTEGRAZIONE”. https://www.sprar.it/wp-content/ uploads/2016/06/Rapporto_Team_integrazione_Arci-Caritas-CIR.pdf

Sciurba, A. (2017). Categorizing migrants by undermining the right to asylum. The implementation of the «hotspot approach» in Sicily. Etnografia e ricerca qualitativa, 10(1), 97-120.

Semprebon, M. (2010). The making of urban safety and immigrants' political engagement in Italy. A comparative ethnography of local conflicts in Verona and Modena. Unpublished $\mathrm{PhD}$ thesis, University of Milan-Bicocca.

Semprebon, M. (2017). Il protagonismo dei rifugiati. Frammenti di inclusione lavorativa in Valle Camonica. In M. Colombo (Ed.), Annuario CIRMiB 2017. Immigrazione e contesti locali. Milano: Vita e Pensiero.

Sprar. (2017). Atlante SPRAR 2016. http://www.interno.gov.it/sites/default/files/allegati/atlante_ sprar_2016_2017_rapporto_leggero.pdf

Stege, U. (2018). I miseri vent'anni di attuazione del sistema Dublino in Europa... e ora? In M. C. Molfetta \& C. Marchetti (Eds.), Il diritto d'asilo. Report 2018. Accogliere, proteggere, promиovere, integrare. Roma: Fondazione Migrantes.

Tazzioli, M. (2017). Containment through mobility: Migrants' spatial disobediences and the reshaping of control through the hotspot system. Journal of Ethnic and Migration Studies. https://doi.org/10.1080/1369183X.2017.1401514. 
Tyler, I. (2010). Designed to fail: A biopolitics of British citizenship. Citizenship Studies, 14(1), 61-74.

Varsanyi, M. W. (2006). Interrogating 'urban citizenship' vis a vis undocumented migration. Citizenship Studies, 10, 229-249.

Vermeulen, F., \& Stotijn, R. (2010). Local policies concerning unemployment among immigrant youth in Amsterdam and in Berlin: Towards strategic replacement and pragmatic accommodation. In T. Caponio \& M. Borkert (Eds.), The local dimension of migration policymaking (IMISCOE reports) (pp. 109-134). Amsterdam: University Press.

Zetter, R. (2007). More labels, fewer refugees: Remaking the refugee label in an era of globalization. Journal of Refugee Studies, 20, 172-192.

Open Access This chapter is licensed under the terms of the Creative Commons Attribution 4.0 International License (http://creativecommons.org/licenses/by/4.0/), which permits use, sharing, adaptation, distribution and reproduction in any medium or format, as long as you give appropriate credit to the original author(s) and the source, provide a link to the Creative Commons license and indicate if changes were made.

The images or other third party material in this chapter are included in the chapter's Creative Commons license, unless indicated otherwise in a credit line to the material. If material is not included in the chapter's Creative Commons license and your intended use is not permitted by statutory regulation or exceeds the permitted use, you will need to obtain permission directly from the copyright holder. 